\title{
Vacunas SARS-CoV-2: evolución y escape
}

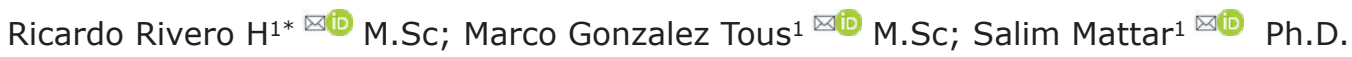

${ }^{1}$ Universidad de Córdoba, Facultad de Medicina Veterinaria y Zootecnia, Instituto de Investigaciones Biológicas del Trópico IIBT, Montería, Córdoba, Colombia.

*Correspondence: ricardoriveroh@correo.unicordoba.edu.co

Recibido: Abril 2021; Aceptado: Abril 2021; Publicado: Abril 2021.

EI SARS-CoV-2 fue declarado un virus pandémico hace un año y ha causado más de 130 millones de casos confirmados y 2.8 millones de muertes alrededor del mundo (1). A finales de 2020, las vacunas basadas en la proteína spike de SARS-CoV-2 fueron las primeras aprobadas en la emergencia sanitaria. La proteína spike interacciona con el receptor ACE2 humano en el inicio del proceso de infección, este conocimiento básico fue el inicio del diseño de una vacuna que tuviera como blanco de acción el spike para que de esa forma desencadenara la acción de los anticuerpos neutralizantes (2). Las vacunas aplicadas en el hemisferio occidental no siguieron la vía tradicional de los virus atenuados o inactivos; la nueva estrategia son las metodologías de ARN mensajero, algunos insertados en vectores virales que presentan el antígeno ante las células del sistema inmune e inducen memoria humoral. Sin embargo, existen vacunas basadas en péptidos recombinantes, virus atenuados e inactivos, aplicadas exitosamente en Latinoamérica y Asia que superan las limitaciones de la temperatura de almacenamiento y aspectos geopolíticos.

Entre las vacunas que utilizan la metodología del ARNm, se encuentran las farmacéuticas Pfizer y Moderna que obtuvieron resultados prometedores en ensayos clínicos de fase III, mostrando eficacia $>94 \%(3,4)$. Entre las vacunas que utilizan la metodología de vector viral se encuentran las de las farmacéuticas AstraZeneca (AZD1222), Johnson \& Johnson (JNJ- 78436735) y la rusa Gam-COVIDVac (Sputnik V), ellas han mostrado una eficacia de 63, 66 y $91.6 \%$ respectivamente. Todas ellas logran disminuir el riesgo de enfermedad severa en un $100 \%(5,6,7)$. Por otra parte, la farmacéutica china Sinovac desarrolló con éxito la vacuna Coronavac que utiliza virus completo inactivado con $\beta$-propiolactona, su eficacia de protección contra la enfermedad es del $50.65 \%$ y del $100 \%$ para casos severos y fatales (8).

A pesar del rápido diseño y éxito de las vacunas, en los últimos meses a través de la vigilancia genómica se han descubierto cepas virales que presentan mutaciones en los sitios inmunodominantes de la proteína Spike. Entre ellos están el Dominio de Unión al Receptor (RBD) y el Dominio N-terminal (NTD) dándole la capacidad de escapar a la neutralización por parte de los anticuerpos. Una de las variantes de mayor importancia a nivel mundial es la sudafricana, conocida como B.1.351 o 501Y.V2 la cual presenta 3 mutaciones en la RBD (K417N, E484K, y N501Y) y ha mostrado tener la capacidad de escapar a la neutralización por sueros de pacientes convalecientes (9). Además, se han observado casos de reinfección en pacientes infectados con las variantes del Reino Unido (B.1.1.7) y Brasil (P.1). Estas mutaciones que se han presentado tan rápidamente no deberían extrañarnos, ya que los virus ARN como el SARS-CoV-2, presentan una alta tasa de mutación de forma natural (10). 
Teniendo presente la evasión inmunológica que tiene el virus: ¿cuánto tiempo podrán mantener su eficacia las vacunas que actualmente se están aplicando? Algunos estudios sugieren que la presencia de mutaciones en RBD disminuye entre 2.3 y 6.4 veces la eficacia de anticuerpos neutralizantes provenientes del plasma de individuos inmunizados con una o dos dosis de mRNA-1273 (Moderna) (11) y aproximadamente 10 veces en el caso de BNT162b2 (Pfizer) (12); esto podría causar que pacientes vacunados se contagien con variantes tales como B.1.351 o P.1 (13). En Colombia ya se ha reportado la circulación de P.1 (Brasil), B.1.17 (UK) y B.1.351 (Sudáfrica) y otras variantes autóctonas con mutaciones en RBD y NTD como B.1+E484K y B.1.160+E484K. Uno de los impactos que ha tenido el escape inmunológico de los virus a la respuesta inmune se ve reflejado en la administración de plasma de pacientes convalecientes. El uso de plasma de un paciente que superó la infección sintomática no garantiza el éxito terapéutico en los pacientes receptores. La cuantificación de anticuerpos neutralizantes es esencial para administrar plasma convaleciente, ya que podría no contener una cantidad importante de anticuerpos sin, enfrentar al virus a concentraciones subóptimas de nABs, ejerce presión selectiva que conduce a la aparición de nuevas variantes con resistentes a la acción de los anticuerpos del paciente (14).

Debido a la evolución natural de virus y a la presión selectiva de las mismas vacunas, es indispensable establecer una vigilancia genómica exhaustiva para identificar las posibles mutaciones que le confieran a los virus la evasión de los anticuerpos neutralizantes. De momento, se han identificado las mutaciones que tienen un impacto en la disminución de anticuerpos neutralizantes, lo que hace debilitar la acción de las vacunas ante las principales variantes de Brasil, Reino Unido y Sudáfrica (K417N, E484K y N501Y). Es importante la vigilancia genómica de variantes autóctonas para detectar las posibles mutaciones. De esta manera se podrán tomar decisiones con relación a la posible modificación de la estructura molecular de vacunas. La formulación de una nueva vacuna que contenga las mutaciones de la proteína spike (K417N, E484K y N501Y), sumado a las prácticas de bioseguridad, son las opciones que prevalecen para la contención de este virus pandémico $(10,15)$.

\section{REFERENCIAS}

1. Worldometer. COVID-19 coronavirus pandemic. [Internet]. Worldometer; 2021. Available from: https://www.worldometers. info/coronavirus/

2. Premkumar $L$, Segovia-Chumbez $B$, Jadi $R$, Martinez DR, Raut R, Markmann AJ, et al. The receptor-binding domain of the viral spike protein is an immunodominant and highly specific target of antibodies in SARS-CoV-2 patients. Sci Immunol. 2020; 5(48):eabc8413. https://doi.org/10.1126/ sciimmunol.abc 8413

3. Polack FP, Thomas SJ, Kitchin N, Absalon J, Gurtman A, Lockhart S, et al. Safety and efficacy of the BNT162b2 mRNA Covid-19 vaccine. N Engl J Med. 2020; 383(27):2603-2615. https://doi. org/10.1056/NEJMoa2034577
4. Baden LR, El Sahly HM, Essink B, Kotloff K, Frey $S$, Novak R, et al. Efficacy and Safety of the mRNA-1273 SARS-CoV-2 Vaccine. N Engl J Med. 2021; 384(5):403-416. https:// doi.org/10.1056/NEJMoa2035389

5. NIH. Janssen Investigational COVID-19 Vaccine: Interim Analysis of Phase 3 Clinical Data Released. USA: National Institutes of Health (NIH); 2021. https://www.nih. gov/news-events/news-releases/jansseninvestigational-covid-19-vaccine-interimanalysis-phase-3-clinical-data-released 
6. AstraZeneca. COVID-19 Vaccine AstraZeneca confirms $100 \%$ protection against severe disease, hospitalisation and death in the primary analysis of Phase III trials [Internet]. Cambridge, UK, AstraZeneca; 2021. https://www.astrazeneca.com/mediacentre/press-releases/2021/covid-19vaccine-astrazeneca-confirms-protectionagainst-severe-disease-hospitalisation-anddeath-in-the-primary-analysis-of-phase-iiitrials.html

7. Logunov DY, Dolzhikova I V., Shcheblyakov D V., Tukhvatulin AI, Zubkova O V., Dzharullaeva AS, et al. Safety and efficacy of an rAd26 and rAd5 vector-based heterologous prime-boost COVID-19 vaccine: an interim analysis of a randomised controlled phase 3 trial in Russia. Lancet. $2021 \mathrm{Feb}$ 20; 397(10275):671-81. https://doi. org/10.1016/S0140-6736(21)00234-8

8. Sinovac Announces Phase III Results of Its COVID-19 Vaccine-SINOVAC - Supply Vaccines to Eliminate Human Diseases. Available from: http://www.sinovac. com/?optionid=754\&auto_id=922

9. Wibmer CK, Ayres F, Hermanus $T$, Madzivhandila $M$, Kgagudi $P$, Oosthuysen B, et al. SARS-CoV-2 501Y.V2 escapes neutralization by South African COVID-19 donor plasma. Nat Med. 2021; https://doi. org/10.1038/s41591-021-01285-x
10. Callaway E. The coronavirus is mutating - does it matter? Nature. 2020; 585:174177. https://doi.org/10.1038/d41586-020$\underline{02544-6}$

11. Wu K, Werner AP, Koch M, Choi A, Narayanan $E$, Stewart-Jones GBE, et al. Serum Neutralizing Activity Elicited by mRNA-1273 Vaccine. N Engl J Med. 2021. https://doi. org/10.1056/NEJMc2102179

12. Wang $Z$, Schmidt $F$, Weisblum $Y$, Muecksch $F$, Barnes $C O$, Finkin $S$, et al. mRNA vaccineelicited antibodies to SARS-CoV-2 and circulating variants. Nature. 2021. https:// doi.org/10.1038/s41586-021-03324-6

13. Garcia-Beltran WF, Lam EC, St. Denis $K$, Nitido AD, Garcia ZH, Hauser BM, et al. Multiple SARS-CoV-2 variants escape neutralization by vaccine-induced humoral immunity. Cell. 2021; 184:1-12. https:// doi.org/10.1016/j.cell.2021.03.013

14. van Egeren D, Novokhodko $A$, Stoddard M, Tran U, Zetter B, Rogers $M$, et al. Risk of evolutionary escape from neutralizing antibodies targeting SARS-CoV-2 spike protein. medRxiv. $2020 ; 11.17 .20233726$. https://doi. org/10.1101/2020.11.17.20233726

15. Weisblum $Y$, Schmidt F, Zhang F, DaSilva J, Poston D, Lorenzi JC, et al. Escape from neutralizing antibodies by SARS-CoV-2 spike protein variants. elife. 2020; 9: e61312. https://doi.org/10.7554/eLife.61312 